\title{
Monilinia vaccinii-corymbosi Apothecial Development Associated With Mulch Depth and Timing of Application
}

\author{
Jade Florence and Jay Pscheidt, Oregon State University, Botany \& Plant Pathology, Corvallis, OR
}

\begin{abstract}
Pseudosclerotia of Monilinia vaccinii-corymbosi overwinter on the soil surface and develop apothecia in early spring, supplying primary inoculum for mummy berry disease of blueberry. Burial of pseudosclerotia in soil and incubation in the dark have previously been identified as critical factors inhibiting M. vaccinii-corymbosi apothecial development. Mulches of Douglas-fir (Pseudotsuga menziesii) sawdust at 2.5 or $5 \mathrm{~cm}$ depths, blueberry leaves (Vaccinium corymbosum cv. Bluetta) at a $2.5 \mathrm{~cm}$ depth, and a bare ground (no mulch) control were assessed for an effect on apothecial development in the spring for 2 years. Mulches were applied corresponding to pseudosclerotial overwintering stages.

Loss of mulch depth was also assessed throughout the overwintering season. A $5 \mathrm{~cm}$ depth of Douglas-fir sawdust was associated with greater apothecial suppression in comparison with bare ground. Douglas-fir sawdust at a $2.5 \mathrm{~cm}$ depth varied in effectiveness, while $2.5 \mathrm{~cm}$ of blueberry leaves was not more effective at suppressing apothecial development than the bare ground treatment. Application timing did not affect apothecial development, but mulches lost significantly more depth when applied at the beginning of the overwintering season as compared with late winter mulches. Therefore, loss of mulch thickness due to weathering and/or decomposition may also affect apothecial development.
\end{abstract}

Mummy berry disease, caused by the fungal pathogen Monilinia vaccinii-corymbosi (Reade) Honey, is a disease of economic concern in areas of blueberry (Vaccinium spp.) production from the southern United States to Canada (Batra 1983, 1991; Honey 1936). Mummy berry disease epidemics in North America have been reported from 1956 up to the present. Documented losses have reached up to 70 to $85 \%$ and cost entire regions up to $\$ 750,000$ (Lockhart 1961; Pepin and Toms 1969; Wallace et al. 1976). In a 2014-15 survey of organic blueberry growers in Oregon and Washington during a series of mummy berry disease workshops, $24 \%$ and $34 \%$, respectively, of Oregon and Washington respondents reported an estimated 6 to $35 \%$ loss due to mummy berry disease in the previous season (Florence 2016b). In the same surveys, 3 and 10\%, respectively, of surveyed Oregon and Washington blueberry growers had a greater than 36\% loss due to mummy berry disease in the previous season (Florence 2016b).

M. vaccinii-corymbosi infects Vaccinium spp. in two discrete events. Primary infection begins when pseudosclerotia overwintering on the soil surface develop apothecia at bud break and eject ascospores (Batra 1983, 1991; Honey 1936). If viable ascospores contact newly formed vegetative or floral host tissue, a primary infection can result. Conidia are then produced and are vectored by pollinators to open flowers at anthesis (Batra and Batra 1985; Cox and Scherm 2001). The fungus then colonizes host floral tissue and subsequent fruit, producing new pseudosclerotia and resulting in a direct loss for growers (Shinners and Olson 1996). These pseudosclerotia will then fall from the bush prior to and during harvest and overwinter, providing inoculum for the following season.

Recommended methods to manage mummy berry disease target the pathogen throughout its life cycle. Planting resistant cultivars is a common recommendation both during operation establishment and to replace susceptible cultivars (Pscheidt and Ocamb 2015; Stretch and Ehlenfeldt 2000). Growers may also choose to collect pseudosclerotia from the blueberry bush during harvest to prevent pseudosclerotia from reaching the ground (Pscheidt and Ocamb 2015). While pseudosclerotia overwinter, it is suggested that producers cultivate the ground to either bury pseudosclerotia prior to

Corresponding author emails: jade.a.florence@gmail.com and pscheidj@ science.oregonstate.edu

Accepted for publication 5 September 2016.

C) 2017 The American Phytopathological Society bud break (Ngugi et al. 2002) or disrupt apothecia development during the primary infection period (Pscheidt and Ocamb 2015). Spray application extends throughout the primary and secondary infection periods; it typically begins at bud break of the earliest cultivar and commences when flowering ends (Pscheidt and Ocamb 2015). Chemical spray application can provide adequate levels of protection against mummy berry disease (Pscheidt and Ocamb 2015). However, current registered organic and biological sprays have been shown to be ineffective (Drummond et al. 2009; Pscheidt and Ocamb 2015). Oregon blueberry growers widely have trouble managing this disease with the tools available, especially in organic production (Florence 2016b; Pscheidt and Ocamb 2015).

A previous study demonstrated that burial of pseudosclerotia at least $2.5 \mathrm{~cm}$ below the soil surface or incubating pseudosclerotia in a dark environment completely inhibits apothecial development under laboratory conditions (Milholland 1974). This was further explored in a field study that demonstrated that mummy berry disease primary infection was significantly decreased by mulching blueberry bushes with $3 \mathrm{~cm}$ of peat moss immediately prior to carpogenic germination (Annis et al. 2010). Mulching is a common horticultural practice in Pacific Northwest blueberry production (Florence and Pscheidt 2015; Roberts and Mellenthin 1959; Strik 2008), but additional studies are needed to assess the effects of mulch type and burial depth on apothecial development. Based on the literature, burial of pseudosclerotia under $2.5 \mathrm{~cm}$ of Douglas-fir sawdust would be expected to significantly decrease apothecial development in comparison with pseudosclerotia resting on the soil surface (Milholland 1974).

Other studies have determined that certain overwintering stages of $M$. vaccinii-corymbosi pseudosclerotia are more vulnerable to decay than others. The degree of maturation, characterized by the presence of melanized entostromata, nonmelanized entostromata, and undifferentiated mycelia within a pseudosclerotium at the time of abscission from the blueberry bush, significantly influences survival of pseudosclerotia (Cox and Scherm 2001). Soaking germinated pseudosclerotia in water can also have differing effects on pseudosclerotial survival when applied at different stages of the overwintering cycle (Bristow 1979). Additionally, there are chill hour and degree-day requirements that must be satisfied in order for a pseudosclerotium to successfully produce an apothecium at the end of the overwintering season (Scherm et al. 2001). Therefore, it follows that burial at certain stages of overwintering may have differing impacts on pseudosclerotial survival and subsequent apothecial development.

Sawdust decomposes relatively slowly over time in comparison with other common mulches such as an equal weight of straw 
(Allison and Anderson 1951; Roberts and Mellenthin 1959). Douglasfir sawdust in particular decomposes at a rate of approximately $2.5 \mathrm{~cm}$ (1 inch) per year under Willamette Valley, OR, conditions (Strik 2008). However, the rate of mulch depth loss during the overwintering period, which lasts from October to March annually, has not been investigated. It is expected that earlier mulches applied during the overwintering season will result in greater loss of mulch depth.

The objectives of this study were to (i) characterize stages of pseudosclerotial overwintering development in the Pacific Northwest; (ii) assess the effect of mulch type and application timing on apothecial development of $M$. vaccinii-corymbosi; and (iii) document the loss in Douglas-fir sawdust mulch depth during the overwintering period.

\section{Materials and Methods}

Source of pseudosclerotia. During the summer of 2013 and 2014, pseudosclerotia were collected from blueberry bushes throughout the harvest season at a commercial organic blueberry farm in Eugene, Oregon. Cultivars included Collins, Earliblue, Darrow, Duke, Reka, Brigitta, Bluecrop, and North Blue. Fruit was sorted on site and pseudosclerotia were brought to the Oregon State University (OSU) Plant Pathology Field Lab, Corvallis, OR, where they were air-dried on screen benches for one week, then stored in brown paper bags at ambient room temperature until use in field experiments. Only pseudosclerotia harvested during the same year were used in each of the field experiments.

Stages of pseudosclerotial development. In early September 2013, approximately 2,000 mature pseudosclerotia from the inoculum source described above were distributed beneath 17-year-old blueberry bushes cv. Berkeley at the OSU Plant Pathology Field Lab. The following year, in September 2014, pseudosclerotia were again placed into the field. To aid in collection during the 2014 overwintering season, 100 pseudosclerotia were placed into each of five 2.7 liter plastic nursery pots with the bottoms removed (termed "corrals") and installed beneath the same plot of blueberry bushes cv. Berkeley from the previous year. In October 2014, four more corrals were installed and 100 pseudosclerotia were again placed inside each

Table 1. Description of pseudosclerotial developmental stages of overwintering. This classification scheme was derived from existing terminology and observations of naturally conditioned pseudosclerotia. Pseudosclerotia first enter the maturation stage in late summer during blueberry harvest. Pseudosclerotia then become dormant when the outer exocarp is shed. Germination begins when stipe initials form, then pseudosclerotia enter the emergence stage when stipes elongate. Stipes become fleshy in the differentiation stage and produce mature spores during the carpogenic germination stage. In the present study, mulch was applied to overwintering pseudosclerotia during the maturation, dormancy, germination/emergence, and differentiation stages. In 2013-14 maturation, dormancy, germination/emergence, and differentiation mulches occurred on 27 October, 13 November, 21 February, and 7 March, respectively. In 2014-15, maturation, dormancy, germination/emergence, and differentiation mulches occurred on 20 October, 20 November, 19 January, and 16 March, respectively. Table adapted from Florence 2016a

\begin{tabular}{|c|c|}
\hline Stage & Description \\
\hline Maturation & $\begin{array}{l}\text { Pseudosclerotia are characterized by } \\
\text { dehydration of infected berries, which } \\
\text { become shriveled, pinkish purple, and } \\
\text { hardened, and abscise from the bush. }\end{array}$ \\
\hline Dormancy & $\begin{array}{l}\text { Pseudosclerotia that have shed the host } \\
\text { exocarp, revealing melanized hyphae, } \\
\text { overwinter on the soil surface. }\end{array}$ \\
\hline Germination & $\begin{array}{l}\text { Pseudosclerotia develop stipe initials, which } \\
\text { are dark brown hardened protrusions smaller } \\
\text { than } 5 \mathrm{~mm} \text {. }\end{array}$ \\
\hline Emergence & $\begin{array}{l}\text { Stipe initials continue to elongate and grow to } \\
\text { between } 5 \text { and } 15 \mathrm{~mm} \text {. }\end{array}$ \\
\hline Differentiation & $\begin{array}{l}\text { Stipe initials elongate, become fleshy, turn a } \\
\text { light brown color, and produce a tip } \\
\text { indentation that may expand to a diameter } \\
\text { up to } 2 \mathrm{~mm} \text {. }\end{array}$ \\
\hline Carpogenic germination & $\begin{array}{l}\text { The tips of the stipes have expanded wider than } \\
2 \mathrm{~mm} \text {, to become cup-shaped apothecia. }\end{array}$ \\
\hline
\end{tabular}

of the corrals. During the first week of each subsequent month during the 2013-14 and 2014-15 overwintering seasons, whole pseudosclerotia were collected from beneath bushes (in 2013-14) or from within corrals (in 2014-15) and brought back into the laboratory to assess pseudosclerotial developmental stage of overwintering (defined in Table 1). Pseudosclerotia were surveyed during the overwintering months of September, October, November, December, January, and February. Bulk sample sizes in 2013-14 were 198, 198, 199, 107, 107, and 125 respectively in September, October, November, December, January, and February. Bulk sample sizes in 2014-15 were 100, $100,57,63,44$, and 42 respectively in September, October, November, December, January, and February of 2014-15. Bulk sample sizes for pseudosclerotia that were placed outdoors in October 2014 were $100,100,92,88,63$, and 62, respectively, in September, October, November, December, January, and February. These development stages were used to guide the timing of mulch applications. Pseudosclerotia were not collected in the month of March because the last mulch was applied in February in both years.

Mulch type, depth, and application timing. In early September 2013, corrals were installed between 120, 17-year-old, blueberry bushes cv. Bluetta at the OSU Plant Pathology Field Lab. The plot area (six rows of 30 blueberry bushes) was arranged in a split-plot design with mulch application timing assigned to whole plots (four corrals with each corral resting beneath one of four consecutive blueberry bushes) in a completely randomized design and mulch type randomly assigned to subplots (each single corral within the whole plot of four corrals). Mulch application timings corresponded to visible stages of pseudosclerotial overwintering development, which included maturation, dormancy, germination/emergence, and differentiation (Florence 2016a). Mulches were applied to whole plots when at least $20 \%$ of the surveyed overwintering $M$. vaccinii-corymbosi pseudosclerotia were in a particular overwintering stage.

In 2013-14, there were a minimum of five replications for each application timing. In 2014-15, there were six replications of each application timing. One of four mulch treatments was assigned to each subplot, which included a bare ground (or no mulch) control, a $2.5 \mathrm{~cm}$ depth of blueberry leaves cv. Bluetta, a $2.5 \mathrm{~cm}$ depth of Douglas-fir (Pseudotsuga menziesii) sawdust, and a $5 \mathrm{~cm}$ depth of Douglas-fir sawdust. Blueberry leaves were collected on 23 October 2013 and 20 October 2014, then stored at room temperature prior to use. The $2.5 \mathrm{~cm}$ depth of blueberry leaves was chosen to represent a typical depth of annual blueberry leaf fall. Douglas-fir sawdust (The Bark Place, Corvallis, OR) was weathered 2 years before use in the experiment.

During late September of 2013 and 2014, 50 or 100 pseudosclerotia, respectively, were placed into each subplot to begin overwintering. In 2013-14, maturation, dormancy, germination/emergence, and differentiation mulches occurred on 27 October, 13 November, 21 February, and 7 March, respectively. In 2014-15, maturation, dormancy, germination/emergence, and differentiation mulches occurred on 20 October, 20 November, 19 January, and 16 March, respectively. During M. vaccinii-corymbosi carpogenic germination the following spring, the number of apothecia was counted in each subplot with three data collection days occurring in $2014(9,12$, and 18 Mar) and seven data collection days occurring in 2015 (14, 18, 25, and 31 Mar; and 9, 16, and 21 Apr). More data collection days were added in 2015 to capture the total number of apothecia that developed during the prolonged carpogenic germination period.

In preparation for data collection, both years, blueberry leaf treatments were moved on top of mesh screens (positioned approximately $2.5 \mathrm{~cm}$ above the overwintering pseudosclerotia) in each subplot when carpogenic germination began. This was done so that when the screen was lifted, apothecia could be seen developing below the leaf layer. The apothecia developing beneath the blueberry leaves were considered to be important inoculum that may contribute to primary infection, due to the large air pockets within the layer of blueberry leaves, which may aid in aerial spore dispersal. The Douglas-fir sawdust treatments were left undisturbed during carpogenic germination, because there was no apparent air movement observed through the fine bark mulch. Therefore, apothecia counts for the Douglas-fir 
sawdust treatments were based on the number of apothecia that grew through the mulch and were visible from the surface.

Data analysis. The analysis was split into two parts: (i) presenceabsence of apothecia and (ii) a measure of the magnitude of apothecia exposure when at least one apothecium was present.

The binary response of presence-absence was used to assess treatment effects on the probability of complete apothecium suppression during carpogenic germination. For a binary response in a split plot design, one modern approach is a logistic-type generalized linear mixed model (GLMM) that can allow for any overdispersion (extrabinomial variation) at subplot and/or whole plot levels. However, for binary data in a GLMM, the sample sizes are small and the data are sparse (all or nearly all absences) in some treatments. Therefore, initial modeling was used to assess overdispersion and determine whether simpler exact logistic regression models (which assume no overdispersion and work well for small samples sizes and sparseness) could be used. There was no evidence of overdispersion for whole plots or subplots $(P>0.3$ within each year's data after combining $P$ values [Fisher's method] obtained from exact logistic regression analyses within each application stage subset of the data). With the data being consistent with no overdispersion, standard (fixed-effects) exact logistic regression assuming only binomial variation (PROC LOGISTIC, SAS version 9.4) was used to assess the factorial treatment effects of application stage, mulch type, and their interaction.

Among treatments where there was not complete suppression, the measure used for the magnitude of apothecia exposure over the carpogenic germination period was the area under the curve (AUC) for the counts of apothecia across the (unequally-spaced) data collection days. The units then are apothecia-days analogous to degree-days as a measure of heating. The AUC was calculated by the trapezoidal rule summing over sampling days $\left(\sum 1 / 2\left(C_{i}+C_{i+1}\right) \times\left(t_{i+1}-t_{i}\right)\right)$ where, for sampling day $i, C_{i}$ is the apothecia count and $t_{i}$ is the days since the start of sampling. Apothecia exposure when apothecia were not completely suppressed was analyzed as the response for the subset of the data where apothecia were present ( 100 of the 140 subplots in 2014 and 69 of the 116 subplots in 2015). The resulting unbalanced data were analyzed using a linear mixed model for an unbalanced split plot design (fixed effects of application stage, mulch type, and their interaction with whole plots as random effects in PROC MIXED, SAS version 9.4). The response ranged from 1 to 124 in 2013-14 and 1 to 628 in 2014-15 and was log transformed to improve homogeneity of variance and normality.

Collaborator trials. Corrals were installed as described above in early September 2013 at two commercial Willamette Valley blueberry farms. At the Eugene location, field studies were conducted in a mixed stand of mature Collins, Earliblue, and Bluecrop blueberry varieties, approximately 56 to 66 years old. At the Springfield, OR, site, field studies were conducted in a 23 -year-old mixed stand of Bluecrop and Blueray. Treatments were applied in the same split-plot design as described above with all four mulch types. In 2013-14, mulch was applied at maturation, dormancy, and germination in Eugene, and dormancy, germination, and differentiation in Springfield. There were four replications of each application timing in both locations. Only the Eugene field site was used in the 2014-15 trial, for which the dormancy and germination/emergence application timings were applied with all four mulch types. There were six and five replications, respectively, of the dormancy and germination/emergence application timings.

During late October 2013, 35 pseudosclerotia were placed into each subplot at the commercial blueberry farms in Springfield and Eugene. During late September 2014, 50 pseudosclerotia from the inoculum source described above were placed into each subplot at the field site in Eugene. Treatments were applied using the same methods described above. The following spring, apothecia were counted twice per week during the carpogenic germination period. At the collaborator site in Eugene, blueberry leaves cv. Bluetta were left on top of the overwintering pseudosclerotia throughout the carpogenic germination period, moved aside during data collection, then replaced.

For the 2014-15 data, AUC was calculated for each subplot to capture the apothecia counts detected during the carpogenic germination period. The statistical analysis was conducted using the same methods described above for the Corvallis location. There was no evidence of overdispersion for whole plots or subplots $(P=0.94$ and 0.30 within the germination and dormancy overwintering stages respectively, obtained from exact logistic regression analyses). The AUC response variable for analysis 2 ranged from 1 to 224 in 2014-15 and was log transformed to improve homogeneity of variance and normality.

Mulch depth. In 2013 and 2014, blueberry bushes cv. Bluetta with $1.5 \times 3 \mathrm{~m}$ spacing at the OSU Plant Pathology Field Lab were assigned a mulch application timing, in a completely randomized design. Approximately 2.5 to $5 \mathrm{~cm}$ depth of Douglas-fir sawdust was applied under each bush in October, November, and February, which corresponded to the maturation, dormancy, and germination/emergence stages of pseudosclerotia overwintering at the same location. Differentiation occurred just prior to carpogenic germination, so it was not assessed for loss of mulch depth. There were four replications of each application timing. The mulch was applied underneath blueberry bushes from the crown to the drip line. At the time of application, five initial depth measurements $(\mathrm{cm})$ were taken between the crown and the drip line of the blueberry bush. During the $M$. vaccinii-corymbosi carpogenic germination period the following spring, five final depth measurements $(\mathrm{cm})$ were taken.

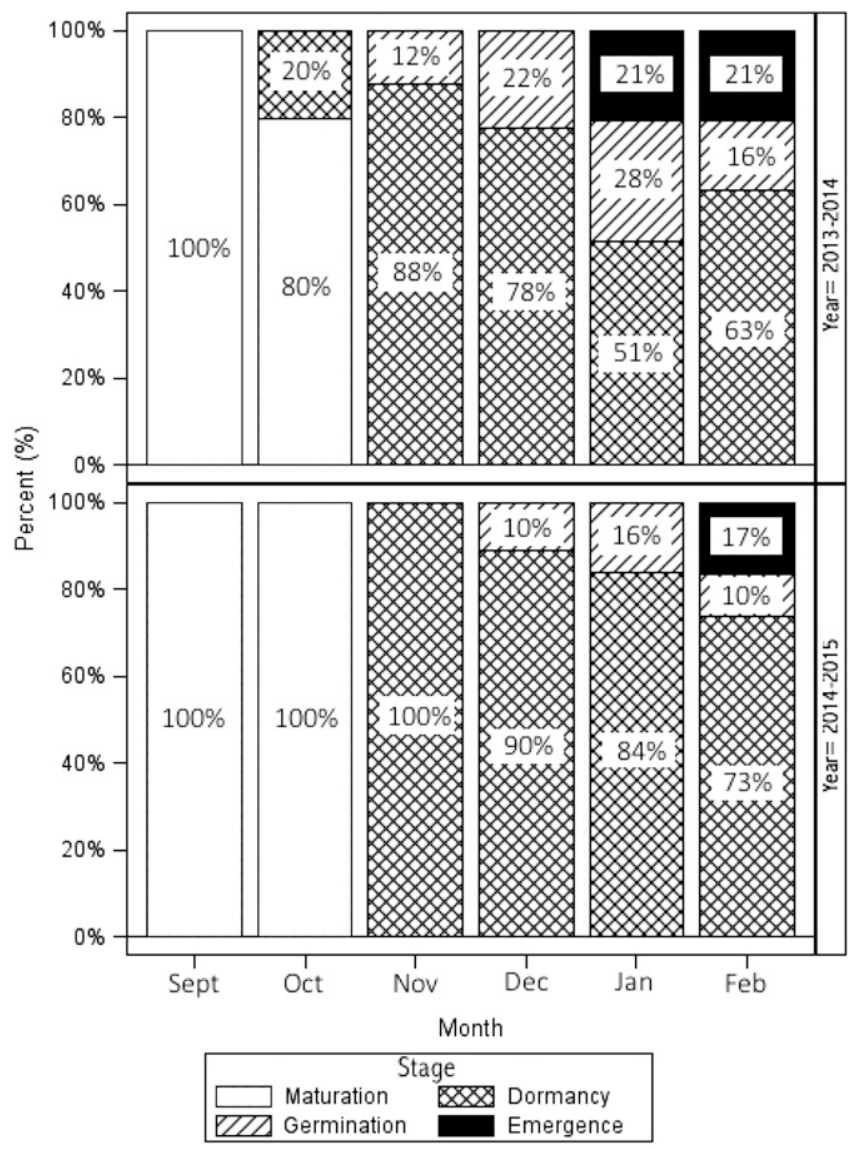

Fig. 1. Percent of sampled Monilinia vaccinii-corymbosi pseudosclerotia that reached particular overwintering stages from September to February in 2013-14 and 2014-15 in Corvallis, OR. Pseudosclerotia at the maturation stage were placed into the field in late September 2013 and 2014 to begin overwintering. Pseudosclerotia were then sampled on the first week of each subsequent month and classified based on pseudosclerotial stages of overwintering (maturation, dormancy, germination, or emergence). Bulk sample sizes in 2013-14 were 198, 198, 199, 107, 107, and 125 respectively in September, October, November, December, January, and February. Bulk sample sizes in 2014-15 were 100,100, 57, 63, 44, and 42 respectively in September, October, November, December, January, and February. Sample data from early September was that of mature pseudosclerotia stored at ambient room temperature prior to placement in the field. 
Final depth was analyzed as the response in a linear model with the fixed factors being year of study, month of mulch application, and their interaction. It was found that after adjusting for year of study, there was no evidence of an overall linear relationship between final depth and initial depth at the individual bush level $(P=0.89)$, so initial depth was not used as a covariate in subsequent modeling. The assumptions of equal variance, normality, and independence were checked and verified following model fitting. Analyses were conducted using SAS version 9.4 (PROC MIXED and PROC GLM).

\section{Results}

Stages of pseudosclerotial development. In both years of the study, pseudosclerotia deteriorated throughout the overwintering period with noticeably fewer intact pseudosclerotia present at later stages of overwintering. Pseudosclerotia placed into the field in late September of both years underwent a complete transition from maturation to dormancy in a 2-month window of October to November (Fig. 1). In the 2013-14 observation year, the population of dormant pseudosclerotia rose from $0 \%$ in September to $88 \%$ in November (Fig. 1A). In the 2014-15 observation year, dormant pseudosclerotia rose from $0 \%$ in September to $100 \%$ in November (Fig. 1B). Only $37 \%$ and $27 \%$ of sampled pseudosclerotia reached the germination/ emergence stages by February 2014 and 2015, respectively (Fig. 1). For pseudosclerotia placed in the field in late October 2014, there was a 1 month delay in the transition from maturation to dormancy, with pseudosclerotia reaching $82 \%$ dormancy in the month of December, and only $2 \%$ of the sample reached the germination/ emergence stage by February 2015 (Fig. 2).

Mulch type, depth, and application timing. In the first presenceabsence analysis, an exact logistic regression with a binary dependent variable was conducted in both years. Application timing did not have a significant effect of apothecial suppression $(P>0.5)$. However, mulch type did have a significant effect on the probability of achieving complete apothecial suppression during the carpogenic germination period $(P<0.0001$ in both years).
In 2013-14, the 2.5 and $5 \mathrm{~cm}$ depths of Douglas-fir sawdust were both associated with more instances of complete apothecial suppression in comparison with the bare ground control $(P<0.0001$ for both comparisons) (Fig. 3). A $5 \mathrm{~cm}$ depth of Douglas-fir sawdust was also more effective at suppressing apothecial development in comparison with the $2.5 \mathrm{~cm}$ depth of Douglas-fir sawdust $(P=0.03)$. There was no difference found between a $2.5 \mathrm{~cm}$ depth of blueberry leaves and the bare ground control $(P=0.2)$. However, pseudosclerotia undergoing carpogenic germination under $2.5 \mathrm{~cm}$ of blueberry leaves were observed developing phototropic apothecia and longer stipes than those growing in the bare ground control.

In 2014-15, only the $5 \mathrm{~cm}$ depth of Douglas-fir sawdust suppressed apothecial development more effectively than the bare ground control $(P<0.0001)$ (Fig. 4). When the Douglas-fir sawdust treatments were compared, a $5 \mathrm{~cm}$ depth of Douglas-fir sawdust was more effective at suppressing apothecial development in comparison with the $2.5 \mathrm{~cm}$ depth $(P=0.0013)$. Neither the $2.5 \mathrm{~cm}$ depth of Douglas-fir sawdust nor the $2.5 \mathrm{~cm}$ depth of blueberry leaves were more effective at suppressing apothecial development than the bare ground control ( $P=0.20$ and 0.66 , respectively). Longer stipes for apothecia developing in the $2.5 \mathrm{~cm}$ of blueberry leaves treatment as compared with the bare ground treatment was also observed this year.

In the second analysis of the magnitude of apothecia exposure provided at least one apothecium was observed, mulch type had a strong effect on the number of apothecia that developed in 2013-14 $(P<0.0001)$, but not in 2014-15 $(P=0.52)$. However, there was some visible evidence of apothecia suppression. In 2014-15, the $5 \mathrm{~cm}$ depth of Douglas-fir sawdust had a lower mean AUC and more total instances of complete suppression in comparison with all other treatments (Fig. 4).

The effect of mulch application timing was not significant in either year ( $P=0.07$ and 0.52 for each year, respectively). Among the $2.5 \mathrm{~cm}$ depth of blueberry leaves and bare ground treatments, which were associated with the highest counts of apothecia, no particular application timings corresponded with increased apothecial suppression in either

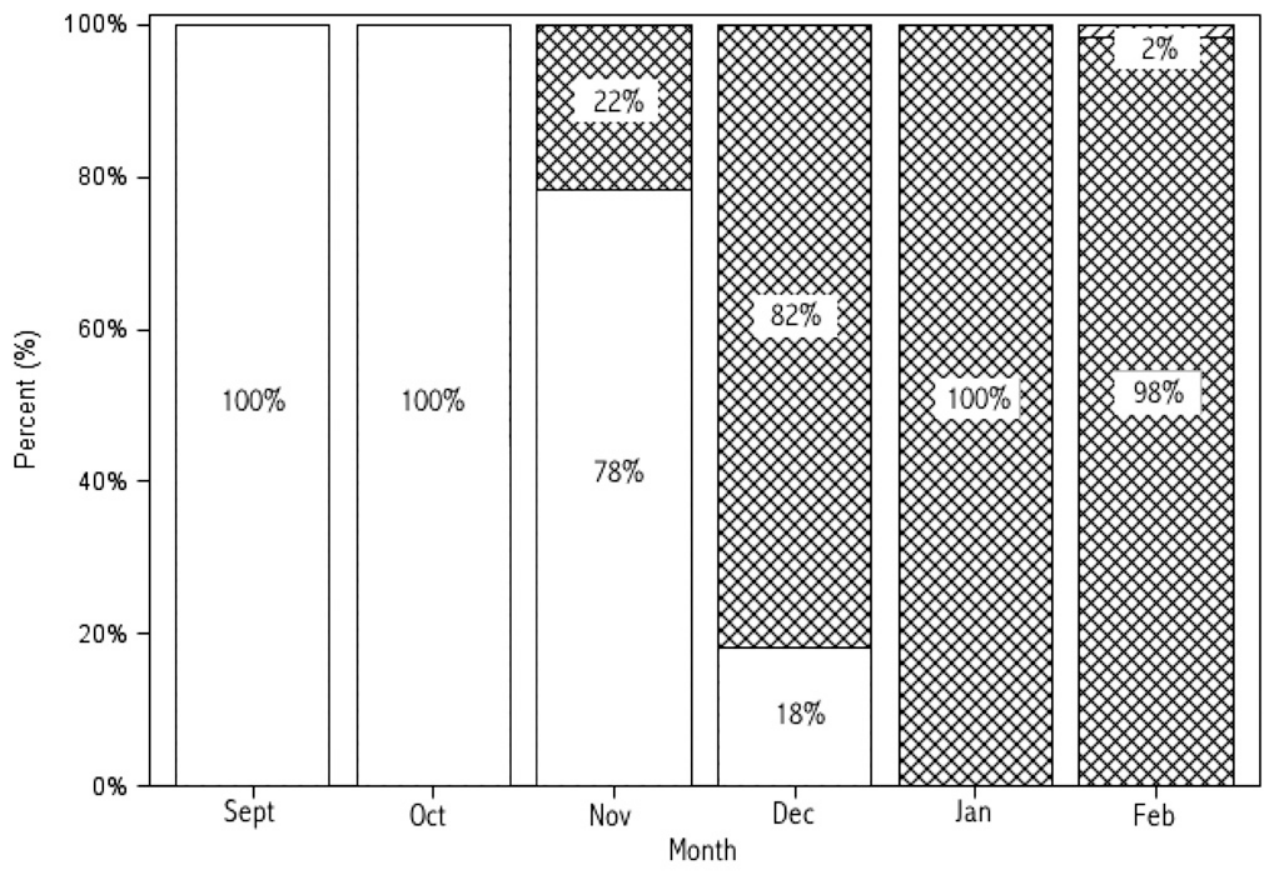

\begin{tabular}{|lllll|}
\hline Stage $\square$ Maturation $\quad 2 \times$ Dormancy & $\square Z Z$ Germination $\square$ Emergence \\
\hline
\end{tabular}

Fig. 2. Percent of sampled Monilinia vaccinii-corymbosi pseudosclerotia that reached particular overwintering stages from September 2014 to February 2015 in Corvallis, OR. Pseudosclerotia were stored at the maturation stage during September and October and were moved outdoors to begin overwintering in late October 2014. Pseudosclerotia were sampled in September, October, November, December, January, and February of 2014-15. Pseudosclerotia were classified based on pseudosclerotial stages of overwintering (maturation, dormancy, germination, and emergence). Percent of sampled pseudosclerotia that reached particular overwintering stages are shown. Bulk sample sizes were 100, 100, 92, 88, 63, and 62, respectively, in September, October, November, December, January, and February. 
year (Fig. 3 and 4). Among the low apothecia counts associated with the 2.5 and $5 \mathrm{~cm}$ depths of Douglas-fir sawdust, there was some evidence that mulch applications occurring earlier in the overwintering season resulted in higher apothecia counts when compared with mulch application timings that occurred later in the season (Fig. 3 and 4).

Collaborator trials. In 2013-14, no apothecia were observed at either collaborator farm. In 2014-15, apothecia were detected at the field site in Eugene. However, statistical analyses failed to indicate any significant effect of mulch type or application timing. Few apothecia were observed developing in the bare ground, $2.5 \mathrm{~cm}$ depth of Douglas-fir sawdust, or $5 \mathrm{~cm}$ depth of Douglas-fir sawdust treatments (Fig. 5). However, a large number of apothecia were detected when $2.5 \mathrm{~cm}$ blueberry leaves were applied at the germination application timing (Fig. 5).

Mulch depth. Year and initial mulch depths covaried, so initial depth was removed from the model. Mulch application month had a strong effect on the final mulch depth (Fig. 6).

An October mulch application was associated with a lower final depth $(\mathrm{cm})$ than a February application across years $(P=0.001)$. A November application, however, was not associated with significantly different final mulch depth when compared with the October or February applications across years $(P>0.05$ for both comparisons). Year also had a significant effect on the final mulch depth $(P=0.015)$, likely due to the difference in initial mulch depth among years. The average initial mulch depth was $3.7(S D=0.6) \mathrm{cm}$ in 2013-14 and $2.2(S D=0.4) \mathrm{cm}$ in 2014-15.

\section{Discussion}

The best mulch depth and material for reducing apothecial development was $5 \mathrm{~cm}$ of Douglas-fir sawdust, which was associated with more instances of complete apothecial suppression than the bare ground treatment in both years. When apothecia did emerge through the $5 \mathrm{~cm}$ depth of Douglas-fir sawdust, evidence was found that mulching reduced the total number of apothecia in comparison with the bare ground treatment in 2013-14. Previous reports have demonstrated that burial of pseudosclerotia at least $2.5 \mathrm{~cm}$ below the soil surface completely inhibited apothecial development (Milholland 1974). Therefore, the use of mulching for mummy berry disease management has previously been recommended for this crop (Retamales and Hancock 2012). In this study, however, pseudosclerotia were not incorporated into the soil, but rather, were buried by applying mulch on top of overwintering pseudosclerotia resting on the soil surface.

The critical depth for burial of M. vaccinii-corymbosi pseudosclerotia with Douglas-fir sawdust appears to lie between the $2.5 \mathrm{~cm}$ and $5 \mathrm{~cm}$ depths, which differs from the 2.5 to $2.6 \mathrm{~cm}$ critical depth previously reported for $M$. vaccinii-corymbosi when soil or peat moss, respectively, were used to bury pseudosclerotia (Annis et al. 2010; Milholland 1974; Ngugi et al. 2002). For S. sclerotiorum, a 2 to $4 \mathrm{~cm}$ critical depth has been reported (Singh and Singh 1983). This suggests that different mulch materials may have unique critical depths, which should be taken into account when choosing alternative mulches. Application timings did not affect the efficacy of

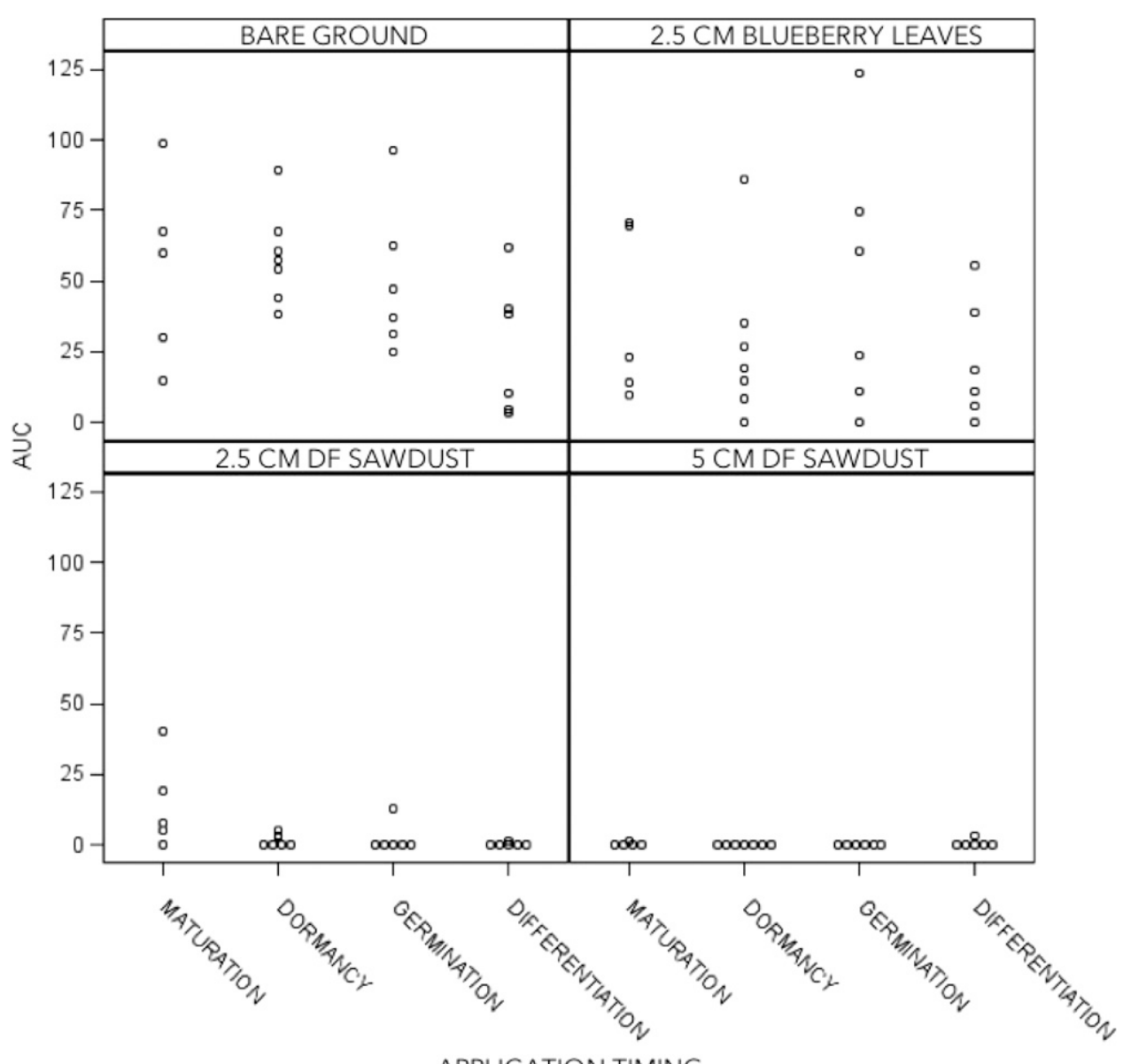

APPLICATION TIMING

Fig. 3. Area under the curve (AUC) of apothecia counts by data collection date for four mulch types applied at one of four distinct overwintering developmental stages of Monilinia vaccini-corymbosi pseudosclerotia in 2013-14. Apothecia counts were plotted by data collection day and the AUC was calculated using a trapezoidal approximation. Pseudosclerotia began overwintering in late September 2013 under blueberry bushes cv. Bluetta in Corvallis, OR. Mulch application timing corresponded to stages of overwintering (maturation, dormancy, germination/emergence, differentiation). Mulch types included bare ground, a $2.5 \mathrm{~cm}$ depth of blueberry leaves, a $2.5 \mathrm{~cm}$ depth of Douglas-fir (DF) sawdust, or a $5 \mathrm{~cm}$ depth of Douglas-fir (DF) sawdust. During the carpogenic germination period in spring 2014, apothecia counts were recorded once per week for each subplot. Data points at AUC $=0$ are displayed side-by-side to show number of zeroes observed. 
mulching for apothecial suppression. Therefore, Douglas-fir sawdust applied to a depth of $5 \mathrm{~cm}$ anytime in the overwintering period is sufficient to reduce apothecial development.

Though mulch application timing did not have an effect on particular overwintering stages, loss of mulch depth throughout the overwintering period may have an effect. A significant change in Douglas-fir sawdust mulch depth was observed in the fall (October) mulch application as compared with the winter (February) application. On an annual basis, Douglas-fir sawdust mulches typically decompose at a rate of about $2.5 \mathrm{~cm}$ in the Pacific Northwest (Roberts and Mellenthin 1959; Strik 2008). Therefore, it is recommended that mulches be applied in late winter to decrease mulch depth loss due to decomposition and/or weathering.

A thin layer ( $2.5 \mathrm{~cm}$ or less) of blueberry leaves cv. Bluetta does not reduce or stimulate apothecial development more effectively than bare ground, but leaves had an observed effect on apothecia morphology. Apothecia in the leaf mulch treatment had an observed increase in stipe length and phototropism as compared with the bare ground treatment. These morphological differences may have been adaptations for dim light environments, as was provided by leaves in this instance.

In 2014-15, leaf treatments at the Corvallis site were moved on top of the mesh screens at carpogenic germination, while leaf treatments at the Eugene site rested directly on top of developing apothecia during the carpogenic germination period. The following spring, at the Corvallis site, the presence of leaf cover neither significantly increased nor decreased apothecial development. Additionally, the presence of the mesh screen with leaves moved on top of it during carpogenic germination resulted in no observable difference in apothecial development than the bare ground treatment.

In contrast, at the Eugene site, large numbers of apothecia were observed beneath leaves applied during the germination stage as compared with the bare ground treatment, but the same effect was not observed for pseudosclerotia covered with leaves during the earlier, dormancy stage. In the literature, it has been reported that apothecia are commonly found beneath fallen blueberry leaves, moss, or other plant debris (Batra 1983). Perhaps the coverage added to subplots during the midwinter germination/emergence period provided protection to the overwintering pseudosclerotia, thus enhancing their survival rate. It is unknown, however, why the dormancy stage did not achieve the same result. While statistically significant differences were not found between the bare ground and leaf treatments, there may have been too much variation, too few observations, or a combination of the two that prevented detection of these differences.

Deployment of pseudosclerotia to begin overwintering in the fall appeared to have a major impact on apothecial development. In 2013-14 at the field site in Corvallis, pseudosclerotia were placed outdoors to begin overwintering in late September. At both collaborator sites, however, pseudosclerotia began overwintering a month later in late October. The following spring, apothecia were detected only at the Corvallis site, while none were detected at either collaborator site. The next field season, pseudosclerotia began overwintering in late

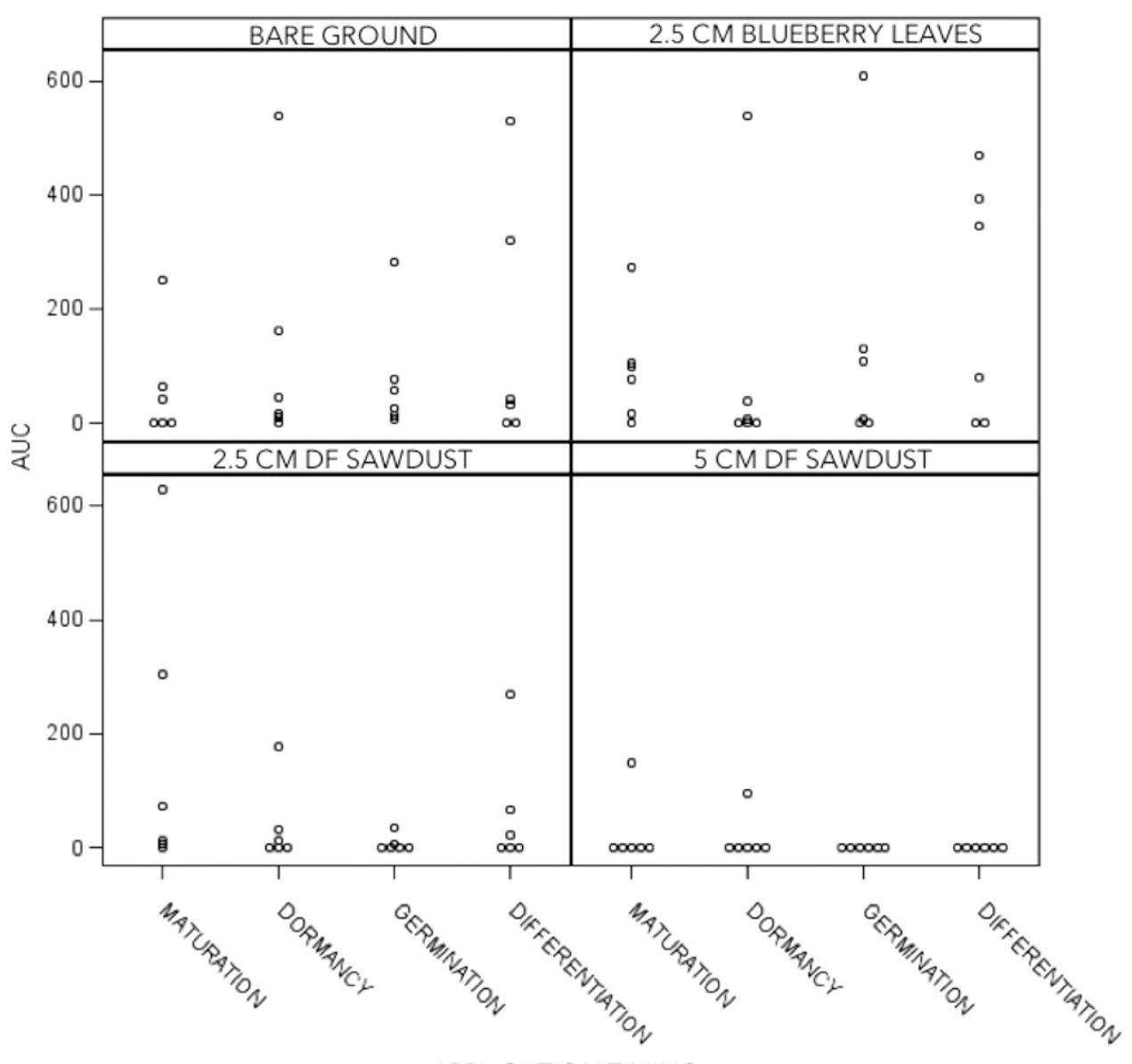

APPLICATION TIMING

Fig. 4. Area under the curve (AUC) of apothecia counts by data collection date for four mulch types applied at one of four distinct overwintering developmental stages of Monilinia vaccini-corymbosi pseudosclerotia in 2014-15. Apothecia counts were plotted by data collection day and the AUC was calculated using a trapezoidal approximation. Pseudosclerotia began overwintering in late September 2013 under blueberry bushes cv. Bluetta in Corvallis, OR. Mulch application timing corresponded to stages of overwintering (maturation, dormancy, germination/emergence, differentiation). Mulch types included bare ground, a $2.5 \mathrm{~cm}$ depth of blueberry leaves, a $2.5 \mathrm{~cm}$ depth of Douglas-fir (DF) sawdust, or a $5 \mathrm{~cm}$ depth of Douglas-fir (DF) sawdust. During the carpogenic germination period in spring 2015, apothecia counts were recorded once per week for each subplot. Data points at AUC $=0$ are displayed side-by-side to show number of zeroes observed. 
September in Corvallis and Eugene, and the following spring, apothecia were detected at both sites. Previous reports indicate that pseudosclerotia removed from the field before the month of November do not germinate, even when subjected to the same number of chill hours (hours with a mean temperature $<7.2^{\circ} \mathrm{C}$ ) as those collected in November or later (Bristow 1979). Perhaps whether removed from the field

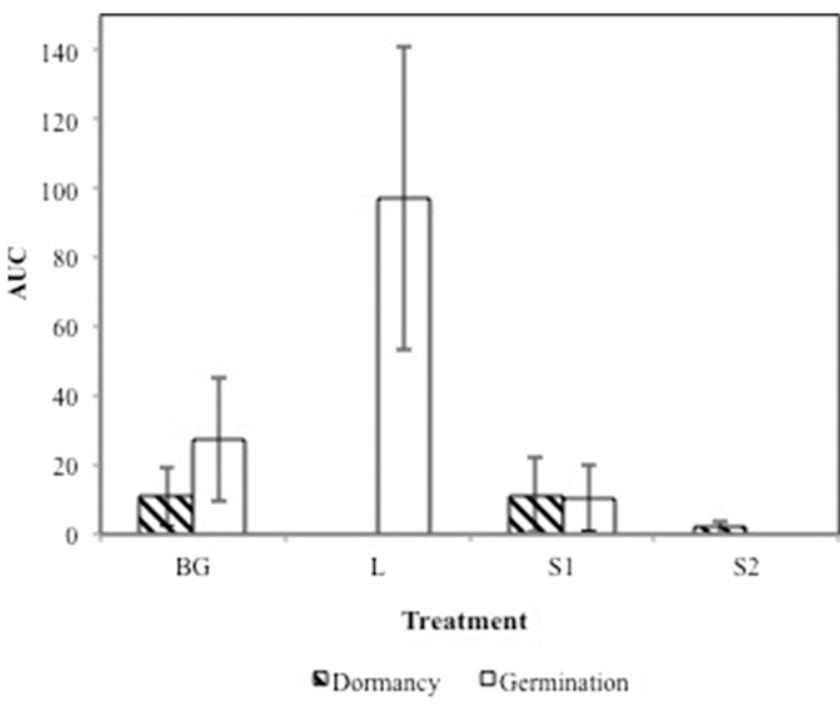

Fig. 5. Mean area under the curve (AUC) for four mulch types applied at one of two distinct overwintering developmental stages of Monilinia vaccinii-corymbosi pseudosclerotia in 2014-15 in Eugene, OR. Apothecia counts were plotted by data collection day and the AUC was calculated using a trapezoidal approximation. M. vaccinii-corymbosi pseudosclerotia began overwintering in late September 2014 under blueberry bushes. Mulch application timing corresponded to stages of overwintering (dormancy, germination/emergence). Mulch types included bare ground (BG), $2.5 \mathrm{~cm}$ blueberry leaves (L), $2.5 \mathrm{~cm}$ Douglas-fir sawdust (S1), or $5 \mathrm{~cm}$ Douglas-fir sawdust (S2). During the carpogenic germination period in spring 2015, apothecia counts were recorded once per week. Mean AUC is plotted with empirical standard error bars. prior to November or entering the field at the end of October, pseudosclerotia in Eugene and Springfield in 2013-14 were deprived of some environmental conditioning that takes place between abscission from the blueberry bush and the beginning of November, which allows them to successfully overwinter and produce apothecia in the spring. This environmental conditioning could be additional maturation, requiring such factors as specific moisture conditions or degree days (base temp $7.2^{\circ} \mathrm{C}$ ) or a photoreception cue similar to that used to trigger dormancy in plants (Wada et al. 2005).

Alternatively, the amount of precipitation was a notable difference between sites during the study. In 2013-14, the Eugene field site had more precipitation (approximately $3.0 \mathrm{~cm}$ ) than the Corvallis site in the same year (approximately $1.5 \mathrm{~cm}$ ) and both sites in the following year (approximately 1.0 and $2.7 \mathrm{~cm}$, respectively). Drainage was a visible problem at the Eugene field site, but not at the Corvallis field site. Therefore, perhaps there was reduced germination due to prolonged soaking, as has been demonstrated in a previous study (Bristow 1979).

Due to the relatively small field plots used in this study, there was an inability to relate a reduction in apothecial development with a reduction in primary infection. However, a previous report successfully associated an early spring mulch with a decrease in $M$. vacciniicorymbosi primary infection (Annis et al. 2010). Similarly, the present study did not address the long-term effects of adding $5 \mathrm{~cm}$ of Douglas-fir sawdust annually. In the Pacific Northwest, it is recommended that $9 \mathrm{~cm}$ of Douglas-fir sawdust be applied initially with $5 \mathrm{~cm}$ added every other year (Julian et al. 2012; Strik 2008). Mulching with Douglas-fir sawdust has the added benefit of enhancing water retention around the root crown, maintaining a slightly acidic soil $\mathrm{pH}$, improving growth, and increasing soil organic matter (Julian et al. 2012; Strik 2008; White 2006). However, a buildup of mulch or mulch applied too deep can lead to a restriction of gas exchange around the root zone (Hanslin et al. 2005), which is bad for plant health. Furthermore, use of a Douglas-fir sawdust mulch can immobilize available $\mathrm{N}$ due to its high C:N ratio (Brady and Weil 1996). Therefore, it is recommended that producers add supplemental $\mathrm{N}$ fertilizer to account for this (Roberts and Mellenthin 1959). Another factor to be considered when using any mulch is that bulk organic material can provide habitat for both beneficial and pest populations

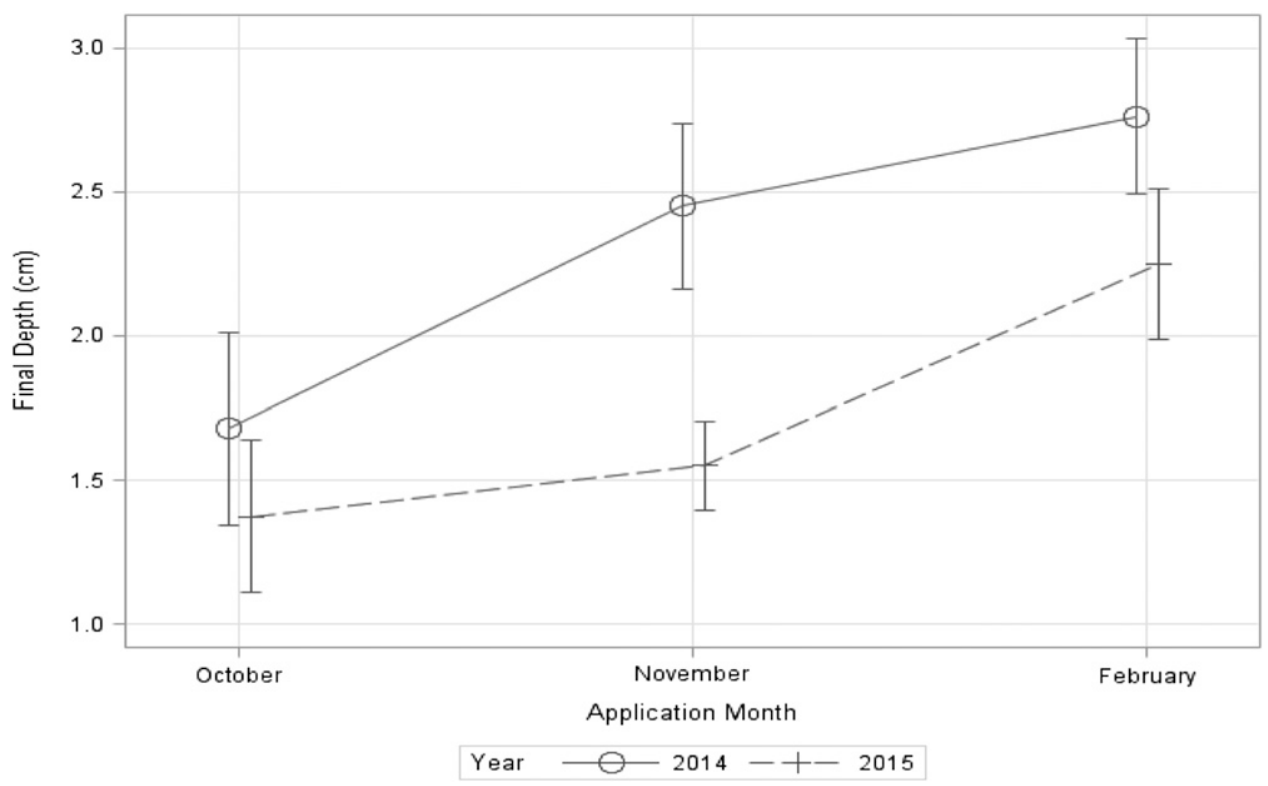

Fig. 6. Final measurements of mulch depth $(\mathrm{cm})$ recorded in March 2014 and 2015 after being applied in October, November, and February during the previous fall and winter. Mulch applications corresponded with Monilinia vaccinii-corymbosi pseudosclerotial overwintering stages (maturation, dormancy, and germination/emergence). Mulches of Douglas-fir sawdust at 2.5-5 cm depths were applied beneath blueberry bushes cv. Bluetta in Corvallis, OR, during the fall and winter months of 2013-14 and 2014-15. There were four replications of each mulch application timing treatment. Error bars show empirical standard error. The connecting lines and are intended to assist the reader in distinguishing between years. 
(Gill et al. 2011; Johnson et al. 2004). However, additional studies will be required to determine the further effects of mulching in blueberry cultivation and how best to combine the horticultural and disease management aspects of this practice, while taking into account mulch decomposition over time. Further research is also needed to determine (i) the distribution of pseudosclerotia on the soil surface after abscission from the blueberry bush, (ii) the effect of leaf mulches applied at a depth $>2.5 \mathrm{~cm}$ on apothecial development, (iii) the effect of other mulch application timings, such as a late summer application, and (iv) the critical depth required when mulching with alternative mulch types. Other mulches may have additional desirable characteristics such as Douglas-fir bark mulch, which has Phytophthora spp. suppression properties (Hoitink 1980; Houck 1962), and porous, black polyethylene mulch, which is widely used for weed control in blueberry cultivation (Strik 2015).

Mulching with Douglas-fir sawdust appears to be a viable option for mummy berry disease management for blueberry growers in the Pacific Northwest. An annual application of at least $5 \mathrm{~cm}$ (2 inches) of Douglas-fir sawdust either in late winter (prior to carpogenic germination) or anytime during the fall and winter months if maintained at or above the $5 \mathrm{~cm}$ minimum depth can help reduce the likelihood of apothecial development in the spring.

\section{Acknowledgments}

Funded in part by the Natural Resource Conservation Service in collaboration with the Northwest Center for Alternatives to Pesticides and the Eugene Water \& Electric Board. We thank Dr. Jennifer Miller for arranging collaborations with commercial blueberry producers; and our producer collaborators for access to their farms.

\section{Literature Cited}

Allison, F. E., and Anderson, M. S. 1951. The use of sawdust for mulches and soil improvement. U.S.D.A. Cir. 891.

Annis, S., McGovern, K., and Yarborough, D. 2010. Mummy berry disease forecast method. University of Maine Extension Publication. University of Maine. Online: https://extension.umaine.edu/blueberries/wp-content/uploads/ sites/56/2010/06/mummyberryforecastingmethod.pdf

Batra, L. R. 1983. Monilinia vaccinii-corymbosi (Sclerotiniaceae): Its biology on blueberry and comparison with related species. Mycologia 75:131-152.

Batra, L. R. 1991. World species of Monilinia (Fungi): Their ecology, biosystematics and control. J. Cramer, Berlin.

Batra, L. R., and Batra, S. W. 1985. Floral mimicry induced by mummy-berry fungus exploits host's pollinators as vectors. Science 228:1011-1013.

Brady, N. C., and Weil, R. R. 1996. The nature and properties of soils. 11th Ed. Prentice-Hall Inc., Upper Saddle River, NJ.

Bristow, P. R. 1979. Mummy berry disease: Mummy germination. Pages 163-169 in: Proceedings of the fourth North American Blueberry Research Workers Conference. J. N. Moore, ed. University of Arkansas, Fayetteville.

Cox, K. D., and Scherm, H. 2001. Oversummer survival of Monilinia vacciniicorymbosi in relation to pseudosclerotial maturity and soil surface environment. Plant Dis. 85:723-730.

Drummond, F., J. Smagula, S. Annis, and D.Yarborough. 2009. Organic wild blueberry production. Maine Agricultural and Forest Experiment Station Bulletin 852 .

Florence, J. 2016a. Overwintering stages of pseudosclerotia development for Monilinia vaccinii-corymbosi, causal agent of mummy berry disease on highbush blueberry in North America. Online. Plant Health Prog. doi:10.1094/ PHP-BR-16-0003

Florence, J. 2016b. Mulching to manage mummy berry of blueberry. Doctoral dissertation. Oregon State University, Corvallis.
Florence, J., and Pscheidt, J. W. 2015. Mummy Berry Management in the Pacific Northwest (EM 9117). Oregon State University Extension Catalog. Retrieved 13 January 2016 from https://catalog.extension.oregonstate.edu/sites/catalog. extension.oregonstate.edu/files/project/pdf/em9117.pdf

Gill, H., Mcsorley, R., and Branham, M. 2011. Effect of organic mulches on soil surface insects and other arthropods. Fla. Entomol. 94:226-232.

Hanslin, H. M., Sæbø, A., and Bergersen, O. 2005. Estimation of oxygen concentration in the soil gas phase beneath compost mulch by means of a simple method. Urban For. Urban Green. 4:37-40.

Hoitink, H. A. J. 1980. Composted bark, a light weight growth medium with fungicidal properties. Plant Dis. 64:142-147.

Honey, E. E. 1936. North American species of Monilinia. I. Occurrence, grouping, and life-histories. Am. J. Bot. 23:100-106.

Houck, L. 1962. Factors influencing development and control of Phytophthora fragariae Hickman, the cause of red stele disease of strawberries. Ph.D. thesis, Oregon State University, Corvallis.

Johnson, J. M., Hough-Goldstein, J. A., and Vangessel, M. J. 2004. Effects of straw mulch on pest insects, predators, and weeds in watermelons and potatoes. Environ. Entomol. 33:1632-1643.

Julian, J. W., Strik, B. C., Larco, H. O., Bryla, D. R., and Sullivan, D. M. 2012 Costs of Establishing Organic Northern Highbush Blueberry: Impacts of Planting Method, Fertilization, and Mulch Type. HortScience 47:866-873.

Lockhart, C. L. 1961. Monilinia twig and blossom blight of lowbush blueberry and its control. Can. J. Plant Sci. 41:336-341.

Milholland, R. D. 1974. Factors affecting apothecium development of Monilinia vaccinii-corymbosi from mummified highbush blueberry fruit. Phytopathology 64:296-300.

Ngugi, H. K., Scherm, H., and NeSmith, D. S. 2002. Distribution of pseudosclerotia of Monilinia vaccinii-corymbosi and risk of apothecial emergence following mechanical cultivation. Phytopathology 92:877-883.

Pepin, H. S., and Toms, H. N. W. 1969. Economic loss from mummy berry of highbush blueberry in coastal British Columbia. Pages 105-107 in: Canada Plant Disease Survey 49.

Pscheidt, J., and Ocamb, C. M. 2015. Pacific Northwest Plant Disease Management Handbook. Oregon State University, Corvallis.

Retamales, J. B., and Hancock, J. F. 2012. Blueberries. CABI, Wallingford, Oxfordshire, U.K.

Roberts, A. M., and Mellenthin, W. M. 1959. Effects of sawdust mulches. 11 Horticultural crops. Tech. Bull, 50.

Scherm, H., Savelle, A. T., and Pusey, P. L. 2001. Interactions between chill-hours and degree-days affect carpogenic germination in Monilinia vacciniicorymbosi. Phytopathology 91:77-83.

Shinners, T. C., and Olson, A. R. 1996. The gynoecial infection pathway of Monilinia vaccinii-corymbosi in lowbush blueberry (Vaccinium angustifolium). Can. J. Plant Sci. 76:493-497.

Singh, U. P., and Singh, R. B. 1983. The effect of soil texture, soil mixture, soil moisture and depth on carpogenic germination of Sclerotinia sclerotiorum. Z. Pflanzenkr. Pflanzenschutz 90:662-669.

Stretch, A. W., and Ehlenfeldt, M. K. 2000. Resistance to the fruit infection phase of mummy berry disease in highbush blueberry cultivars. HortScience 35 1271-1273.

Strik, B. C. 2008. Growing Blueberries in Your Home Garden. EC 1304. Oregon State University Extension Service, Corvallis. Online: https://catalog.extension oregonstate.edu/sites/catalog/files/project/pdf/ec1304.pdf

Strik, B. C. 2015. A review of optimal systems for organic production of blueberry and blackberry for fresh and processed markets in the northwestern United States. Sci. Hortic. (Amsterdam) 208:92-103.

Wada, M., Shimazaki, K., and Iino, M., eds. 2005. Light Sensing in Plants Springer, Tokyo.

Wallace, D. B., MacHardy, W. E., and Meader, E. M. 1976. Control of mummy berry of highbush blueberry in New Hampshire. Plant Dis. Report. 60 97-101.

White, L. 2006. The effect of pre-plant incorporation with sawdust, sawdust mulch, and nitrogen fertilizer rate on soil properties and nitrogen uptake and growth of 'Elliott' highbush blueberry. Oregon State University, Corvallis. 